\title{
The Evolution of Student Free Speech: Tinker and Beyond
}

\author{
John Dayton * and Betul Tarhan
}

Department of Educational Administration and Policy, University of Georgia, Athens, GA 30602, USA; tarhan@uga.edu

* Correspondence: jdayton@uga.edu

\begin{abstract}
There are no secure rights without the right of free speech. Free speech is the right that is necessary to defend all other rights. Student free speech is an essential foundation for societal free speech. We will not have a society that values and protects free speech without valuing and protecting free speech for students. Schools must serve as the essential nurseries of our democracy and as examples of the responsible exercise of rights in a free society including free speech. We cannot expect students to spend most of their waking hours in institutions devoid of meaningful rights to freedom of speech and then emerge as adults prepared to exercise and defend democratic freedoms including free speech. Students who learn to exercise free speech rights in schools are more likely to become adults ready to exercise free speech rights in a civil democracy. This article addresses the ongoing evolution of student free speech rights in the U.S., providing a brief overview of free speech law; a review of student speech law in public K-12 schools and in public higher education institutions; a guide to applying the Tinker test in practice; a discussion of the continuing evolution of student speech law in public educational institutions; a review of freedom of the press in public educational institutions; and conclusions on the evolution of student speech.
\end{abstract}

Keywords: free; speech; student; Tinker test; PK-12

\section{Introduction}

At of the core of the U.S. Constitution's First Amendment free speech protections are Citation: Dayton, John, and Betul Tarhan. 2021. The Evolution of Student Free Speech: Tinker and Beyond. Laws 10: 94. https:// doi.org/10.3390/laws10040094

Received: 29 October 2021 Accepted: 29 November 2021 Published: 6 December 2021

Publisher's Note: MDPI stays neutral with regard to jurisdictional claims in published maps and institutional affiliations. strong protections for individual political and religious speech (Dayton 2019). Political and religious speech are most vigorously protected because these types of speech historically have been the primary targets of government censorship. Government officials always have been tempted to use their official powers to silence critics and to suppress the communication of ideas or information that may threaten the current political or religious regime. Speakers have the right to express their beliefs, and it is up to listeners, not government officials, to decide what is true and worth repeating.

The First Amendment wisely provides broad protections for free speech. But free speech rights cannot be absolute when the free speech of one person threatens the rights or safety of others. As Justice Holmes said: "The most stringent protection of free speech would not protect a man falsely shouting fire in a theater and causing a panic (Schenck $v$. United States 1919, p. 52)". Within an evolving hierarchy of First Amendment protections, the Court generally prohibits content-based censorship, with political and religious speech receiving the greatest protections, commercial speech receiving less rigorous protection, and obscenity falling outside of the scope of constitutional protection (Dayton 2019, supra note 1 , at 140).

The Court recognizes freedom of speech as a fundamental right under the U.S. Constitution. Government officials may only limit fundamental rights, including constitutionally protected speech, by establishing that limitations are necessary to a compelling interest and narrowly tailored to achieving that interest. The Court also has recognized, however, that government officials may apply reasonable time, place, and manner regulations to speech where these regulations are content-neutral; serve an important public interest; and leave open adequate alternative routes of communication (Dayton 2019, supra note 1, at 140). 
Further, the Court has recognized the necessity of different standards for different modes of communication. For example, the Court has allowed greater restrictions on general broadcast communications than on print media (Dayton 2019, supra note 1, at 140). The Court has also recognized different protections in different contexts, vigorously protecting free speech in traditional open public forums such as public streets and parks, and allowing stronger regulations in forums dedicated to limited purposes, such as public business meetings, when these restrictions are warranted under the circumstances and are not a mere pretext for limiting protected speech (Dayton 2019, supra note 1, at 140-41).

Public forums range from open forums such as public parks and streets, to limited open forums including public educational institutions, and closed forums such as meetings on national security or other matters legitimately requiring exclusion of direct public participation. In some circumstances reasonable time, place, and manner restrictions on speech are necessary to preserve the public forum for its intended purposes. These restrictions do not violate the First Amendment when they serve important public interests; do not discriminate based on the political or religious viewpoint of the speaker; and leave open adequate alternative routes for free speech (Dayton 2019, supra note 1, at 141).

Freedom of speech is protected not only for the benefit of individuals, but also to assure the free flow of information that leads to the political, intellectual, and cultural advancement of the society through the marketplace of ideas. Innovative and productive ideas flourish in a free environment where the only limits these ideas are subjected to are the tests of public debate and the reason of an educated and free people. Similarly, ideas that are potentially dangerous to the community are also best refuted in open debate (Dayton 2019, supra note 1, at 141) ${ }^{1}$.

A public educational institution is not, however, a public street or a public park. From the public school through the public university, sufficient order is necessary for effective instruction and other educational activities. School officials must maintain necessary order in the classroom and on the campus to achieve their essential educational missions and to protect the safety and well-being of all persons on the campus. However, public educational institutions are not military units in which free speech exists only in theory, absolute conformity is required, and subordinates are expected to follow all orders immediately and without question or debate (Dayton 2019, supra note 1, at 141).

\section{Student Speech in Public K-12 Schools}

Disputes over free speech frequently have involved public K-12 schools, with the Court addressing the proper balance between individuals' rights of free speech and legitimate institutional needs. In Tinker the Court addressed the scope of students' free speech rights in public educational institutions, establishing the legal foundation for student speech (Tinker v. Des Moines 1969).

In Tinker v. Des Moines, Mary Beth Tinker, a public school student, was punished by public school officials for wearing a black armband protesting against war (Tinker v. Des Moines 1969). The Court held that in cases involving student political speech school officials may only limit this speech if they can establish it would "materially and substantially interfere with the requirements of appropriate discipline in the operation of the school (Tinker v. Des Moines 1969, at 505)" and "where there is no finding and no showing that engaging in the forbidden conduct (Tinker v. Des Moines 1969, at 509)" meets this standard, punishments violate students' free speech rights and "cannot be sustained (Tinker v. Des Moines 1969, at 509)".

In Tinker, the Court famously stated: "It can hardly be argued that either students or teachers shed their constitutional rights to freedom of speech or expression at the schoolhouse gate (Tinker v. Des Moines 1969, at 506)". The Court declared: "Students in school as well as out of school are 'persons' under our Constitution. They are possessed of

1 See also Abrams v. U.S. 1919, 630 (Holmes, J., dissenting) ("the ultimate good desired is better reached by free trade in ideas-that the best test of truth is the power of the thought to get itself accepted in the competition of the marke"). 
fundamental rights which the State must respect, just as they themselves must respect their obligations to the State (Tinker v. Des Moines 1969, at 511)".

Although recognizing a constitutional right to speech by students, the Court has also emphasized the importance of teaching children civility and tolerance. The Court stated in Bethel School District v. Fraser that public schools "must inculcate the habits and manners of civility" and that this must "include tolerance of divergent political and religious views, even when the views expressed may be unpopular (Bethel $v$. Fraser 1986, 680-81) ${ }^{2 /}$. While recognizing students' rights to freedom of speech, the Court has emphasized the accompanying responsibility of exercising civility in expressing their opinions. The Court noted: "Indeed the 'fundamental values necessary to the maintenance of a democratic political system' disfavor the use of terms of debate highly offensive or highly threatening to others .... The inculcation of these values is truly the 'work of the schools (Bethel v. Fraser 1986, 683).'" Courts have recognized that divergent views are tolerated in a democratic society and that civil discourse is the appropriate way to express individual views and opposition to the views of others (Wilson v. Chancellor 1976) ${ }^{3}$.

The Court has also distinguished between individual student speech, as in Tinker v. Des Moines (1969) and student speech in public school sponsored and controlled forums, as in Bethel v. Fraser (1986) and Hazelwood v. Kuhlmeier (1988). In Hazelwood the Court held "educators do not offend the First Amendment by exercising editorial control over the style and content of student speech in school sponsored expressive activities so long as their actions are reasonably related to legitimate pedagogical concerns (Hazelwood v. Kuhlmeier 1988, at 273)". Further, the Court suggested that student speech in public school sponsored forums can be distinguished from individual student speech because school sponsored speech involves "expressive activities that students, parents, and members of the public might reasonably perceive to bear the imprimatur of the school (Hazelwood v. Kuhlmeier 1988, at 271; also Dupre 2008)".

Viewed together, the Court's cases indicate that student speech in public schools generally falls into two categories: (1) student speech involving individual student expression, as in Tinker v. Des Moines (1969) and (2) student speech in public school sponsored forums, as in Bethel v. Fraser (1986) and Hazelwood v. Kuhlmeier (1988). In Tinker the Court declared that to lawfully limit individual student speech, school officials must establish that the speech would "materially and substantially interfere with the requirements of appropriate discipline in the operation of the school (Tinker v. Des Moines 1969, 509) ${ }^{4 \prime}$. Although school officials may apply reasonable time, place, and manner restrictions to student expressive activities, if they cannot establish that the speech "materially and substantially" interferes with "appropriate discipline in the operation of the school" the speech generally cannot be prohibited or punished consistent with the First Amendment (Tinker v. Des Moines 1969).

Concerning student speech in public school sponsored forums, such as school convocations, performances, athletic events, school newspapers, and other expressive activities that students, parents, and members of the public might reasonably perceive as bearing the "imprimatur of the school" (Hazelwood v. Kuhlmeier 1988, 271) school officials generally have much broader discretion to limit student speech. Where the forum for expression is sponsored by the school or reasonably perceived as bearing the imprimatur of the school,

2 See also United States v. Schwimmer 1928, p. 655 (Holmes, J., dissenting) (the Constitution embodies "the principle of free thought-not free thought for those who agree with us but freedom for the thought that we hate").

3 "I am firmly convinced that a course designed to teach students that a free and democratic society is superior to those in which freedoms are sharply curtailed will fail entirely if it fails to teach one important lesson: that the power of the state is never so great that it can silence a man or woman simply because there are those who disagree. Perhaps that carries with it a second lesson: that those who enjoy the blessings of a free society must occasionally bear the burden of listening to others with whom they disagree, even to the point of outrage".

4 "In order for the State in the person of school officials to justify prohibition of a particular expression of opinion, it must be able to show that its action was caused by something more than a mere desire to avoid the discomfort and unpleasantness that always accompany an unpopular viewpoint. Certainly where there is no finding and no showing that engaging in the forbidden conduct would 'materially and substantially interfere with the requirements of appropriate discipline in the operation of the school', the prohibition cannot be sustained". 
as in Bethel v. Fraser 1986, $685^{5}$ and Hazelwood v. Kuhlmeier $(1988)^{6}$, student expression can be limited based on establishing a legitimate educational rationale for limiting the speech (Hazelwood v. Kuhlmeier 1988, 273).

\section{Student Speech in Public Higher Education Institutions}

The factual context for the Court's 1969 decision in Tinker involved children in K-12 public schools (Tinker v. Des Moines 1969). But in 1972 in Healy v. James (1972), the Court made it clear that free speech rights recognized in Tinker applied to public university campuses with even greater force:

At the outset we note that state colleges and universities are not enclaves immune from the sweep of the First Amendment. "It can hardly be argued that either students or teachers shed their constitutional rights to freedom of speech or expression at the schoolhouse gate". Tinker (1969). Of course, as Justice Fortas made clear in Tinker, First Amendment rights must always be applied "in light of the special characteristics of the ... environment" in the particular case. And, where state-operated educational institutions are involved, this Court has long recognized "the need for affirming the comprehensive authority of the States and of school officials, consistent with fundamental constitutional safeguards, to prescribe and control conduct in the schools". Yet, the precedents of this Court leave no room for the view that, because of the acknowledged need for order, First Amendment protections should apply with less force on college campuses than in the community at large. Quite to the contrary, " $(\mathrm{t})$ he vigilant protection of constitutional freedoms is nowhere more vital than in the community of American schools". Shelton v. Tucker, 364 U.S. 479 (1960). The college classroom with its surrounding environs is peculiarly the "marketplace of ideas", and we break no new constitutional ground in reaffirming this Nation's dedication to safeguarding academic freedom. (Healy v. James 1972, at 180-81)

There is no greater marketplace of ideas than a university campus (Healy v. James 1972 , at $180-181)^{7}$. Because free speech rights are strongly protected for children in K-12 public schools, a fortiori, these rights must be even more rigorously protected for adults in public institutions of higher education at the epicenter of the marketplace of ideas and academic freedom (Healy v. James 1972, at 180-81). Therefore it could be logically deduced that the Court's decision in Tinker, protecting rights of free speech in public K-12 schools, also governs public higher education institutions, but with even greater strength, as the Court affirmed in its decision in Healy (Healy v. James 1972, at 180-81).

This same logic does not, however, yield the result that the Court's decisions in Bethel v. Fraser (1986) and Hazelwood v. Kuhlmeier (1988) automatically governed public higher education institutions (Bethel v. Fraser 1986, at 682) ${ }^{8}$. The Court's decisions in Fraser and Hazelwood were clearly directed at K-12 public schools with minor children

\footnotetext{
5 "We hold that petitioner School District acted entirely within its permissible authority in imposing sanctions upon Fraser in response to his offensively lewd and indecent speech. Unlike the sanctions imposed on the students wearing armbands in Tinker, the penalties imposed in this case were unrelated to any political viewpoint. The First Amendment does not prevent the school officials from determining that to permit a vulgar and lewd speech such as respondent's would undermine the school's basic educational mission. A high school assembly or classroom is no place for a sexually explicit monologue directed towards an unsuspecting audience of teenage students".

6 "We hold that educators do not offend the First Amendment by exercising editorial control over the style and content of student speech in school-sponsored expressive activities so long as their actions are reasonably related to legitimate pedagogical concerns".

7 "The college classroom with its surrounding environs is peculiarly the 'marketplace of ideas', and we break no new constitutional ground in reaffirming this Nation's dedication to safeguarding academic freedom".

8 "The First Amendment guarantees wide freedom in matters of adult public discourse. A sharply divided Court upheld the right to express an antidraft viewpoint in a public place, albeit in terms highly offensive to most citizens". See also Cohen v. California 1971. It does not follow, however, that simply because the use of an offensive form of expression may not be prohibited to adults making what the speaker considers a political point, the same latitude must be permitted to children in a public school. In New Jersey v. T.L.O. 1985, 340-42, we reaffirmed that the constitutional rights of students in public school are not automatically coextensive with the rights of adults in other settings. As cogently expressed by Judge Newman, 'the First Amendment gives a high school student the classroom right to wear Tinker's armband, but not Cohen's jacket'".
} 
in attendance ${ }^{9}$. Nonetheless, lower courts continue to apply the legal principles articulated in Fraser/Hazelwood to higher education settings as well, in cases involving both students and faculty challenging limits on speech in school sponsored forums ${ }^{10}$. Based on Fraser/Hazelwood these cases recognize authority to regulate school sponsored speech much more broadly than individual speech, and only require school officials to establish a legitimate educational rationale for limitations on speech in school sponsored forums (Dayton 2019, supra note 1 at 158).

Because members of the university community are not minor children, however, university officials must recognize some greater license for adult students and faculty concerning, for example, indecent speech, i.e., communication of which is prohibited concerning minors but constitutionally protected for adults, especially when the indecent expression is not legitimately subject to reasonable time, place, and manner restrictions and genuinely involves the communication of protected speech for adults ${ }^{11}$.

\section{Applying the Tinker Test in Practice}

According to the Court in Tinker, in cases involving student political speech, school officials may only limit this speech if they can establish it would "materially and substantially interfere with the requirements of appropriate discipline in the operation of the school (Tinker v. Des Moines 1969, at 509)". And "where there is no finding and no showing that engaging in the forbidden conduct" meets this standard "the prohibition cannot be sustained (Tinker $v$. Des Moines 1969, at 509)". This required threshold of showing a "material and substantial" interference is the Court's "Tinker test" used to distinguish between student speech that is protected under the First Amendment and student speech that is subject to prohibition and punishment by school officials in public educational institutions (Dayton 2019, supra note 1, at 146).

In articulating this standard, the Court provided a benchmark for school officials in deciding whether the lawful response to the student speech in question was simply to allow the speech or to attempt to intervene to avoid a "material and substantial" interference with school discipline and operations. Intervention by school officials is lawful when school officials can meet the standard established in Tinker (Dayton 2019, supra note 1 at 146). But where exactly is the line between protected and unprotected student speech, and what must school officials do to comply with the Tinker test?

To answer this question, envision a continuum with protected speech at one end, and prohibited speech at the other end. At the protected speech end of the continuum is speech that is clearly protected by the First Amendment, including legitimate political and religious speech that causes no interference with necessary order or the operations of the school. At the other end of the continuum is speech that is clearly unprotected including obscenity, slander, terroristic threats, and other obviously unprotected student speech that directly threatens safety, discipline, or school operations. It is easy for school officials to make decisions concerning student speech that clearly falls toward either end of this continuum. It is the cases closer to the middle of this continuum that present the greatest challenges for school officials in deciding whether to allow the speech or to intervene (Dayton 2019, supra note 1 at 146).

The Tinker standard is the Court's attempt to provide guidance for school officials and judges in making decisions in these cases nearer the middle of this continuum. But

9 See, Bethel $v$. Fraser 1986, 683-84 ("The speech could well be seriously damaging to its less mature audience, many of whom were only 14 years old and on the threshold of awareness of human sexuality .... We have also recognized an interest in protecting minors from exposure to vulgar and offensive spoken language); Hazelwood $v$. Kuhlmeier 1988 ("We have nonetheless recognized that the First Amendment rights of students in the public schools 'are not automatically coextensive with the rights of adults in other settings'”,), citing Bethel v. Fraser $1986,682$.

10 See, e.g., Martin v. Parrish 1986, 585-86 ("To the extent that Martin's profanity was considered by the college administration to inhibit his effectiveness as a teacher, it need not be tolerated by the college any more than Fraser's indecent speech to the Bethel school assembly"). But see, Hosty $v$. Carter 2005, 739 (Evans, J. dissenting) ("In concluding that Hazelwood extends to a university setting, the majority applies limitations on speech that the Supreme Court created for use in the narrow circumstances of elementary and secondary education. Because these restrictions on free speech rights have no place in the world of college and graduate school, I respectfully dissent"). See also (Martin 2003; Nimick 2006).

11 See, e.g., (Golby 2006); but see, (LaVigne 2008). 
while the Tinker standard is a useful general test against which to measure whether the speech is protected, the Tinker standard is not a "bright-line" test (Dayton 2019, at 147; Dayton 2020, p. 74). Bright-line tests establish a definite, clear line between protected and prohibited conduct. A speed limit sign, for example, provides a bright-line test where going over $55 \mathrm{mph}$ is prohibited while $55 \mathrm{mph}$ and under is lawful. Instead of providing a bright-line test, the Tinker test acts as a standard in the continuum that must be interpreted in the unique context in which the speech occurs. This makes the Tinker test more like a speed limit sign that requires a speed that is "reasonable and prudent under the conditions" rather than providing a definite and absolute limit such as $55 \mathrm{mph}$ (Dayton 2020, p. 74).

For administrative convenience it might seem preferable to have a bright-line test for what speech is permissible and prohibited, for example, a definite list of permissible and prohibited expressive conduct. The problem, of course, is that in human communications context and tone are critically important. The exact same words and conduct may be acceptable in some circumstances and clearly unacceptable in others. Further, the human mind is far too creative to be corralled within the bounds of such a finite list, and students would quickly find creative ways around the listed prohibitions. Bright-line tests are very helpful where simple measures are possible, such as measuring the speed of a vehicle, applying rules based on the property boundaries of the campus, etc. But a bright-line test is unworkable in governing more complex human interactions including student speech (Dayton 2020, p. 74).

A bright-line test for speech would be too simplistic and inflexible to govern the complexities of human interactions. Additionally, such a rigid test would be likely to produce results inconsistent with justice and common sense, punishing some speech that should not be punished, and allowing some speech that clearly should not be allowed. Instead, the Tinker test requires a common-sense consideration of the facts and circumstances in each case to determine whether these facts and circumstances move the speech in question closer to either protected or prohibited speech (Dayton 2020, p. 74).

A careful reading of Tinker and subsequent cases, however, does provide some useful guidance in applying the Tinker test (Tinker v. Des Moines 1969). To justify limiting individual student speech, school officials must show more than a desire to avoid the unpleasantness, discomfort, or minor arguments and disturbances that normally occur with the expression of unpopular views. Further, mere speculation or an abstract, undifferentiated fear of disruption will not suffice (Tinker v. Des Moines 1969, at 508-912). When challenged, school officials must be able to articulate facts and circumstances that would convince a reasonable person that a material and substantial interference was likely (Tinker v. Des Moines 1969, at $\left.509^{13}\right)$.

As noted earlier, the Tinker test does not require school officials to prove there was an actual disruption, nor are school officials required to allow the disruption to occur before intervening (Tinker v. Des Moines 1969, at 507). In order to justify limiting otherwise protected student speech, the Tinker test requires school officials to show through evidence of facts and circumstances that they reasonably anticipated a material and substantial interference with appropriate discipline in the operation of the school (Tinker v. Des Moines 1969 , at 509).

So while the Court noted that the mere "discomfort and unpleasantness that always accompany an unpopular viewpoint (Tinker v. Des Moines 1969, at 509)" are not sufficiently disruptive to establish a material and substantial interference; evidence of violence asso-

12 "In our system, undifferentiated fear or apprehension of disturbance is not enough to overcome the right to freedom of expression. Any departure from absolute regimentation may cause trouble. Any variation from the majority's opinion may inspire fear. Any word spoken, in class, in the lunchroom, or on the campus, that deviates from the views of another person may start an argument or cause a disturbance. But our Constitution says we must take this risk, and our history says that it is this sort of hazardous freedom — this kind of openness-that is the basis of our national strength and of the independence and vigor of Americans who grow up and live in this relatively permissive, often disputatious, society".

13 "In order for the State in the person of school officials to justify prohibition of a particular expression of opinion, it must be able to show that its action was caused by something more than a mere desire to avoid the discomfort and unpleasantness that always accompany an unpopular viewpoint. Certainly where there is no finding and no showing that engaging in the forbidden conduct would 'materially and substantially interfere with the requirements of appropriate discipline in the operation of the school', the prohibition cannot be sustained". 
ciated with such conduct; threats of violence; acts of intimidation; significant property destruction or vandalism; substantial disorder; invasion of the rights of others; or sufficient disruption of the educational process, work, order, or discipline of the school would constitute a material and substantial interference under the Tinker test (Tinker v. Des Moines 1969, at 509).

In Healy v. James (1972) the Court also recognized the legitimacy of an institutional requirement, for any group seeking institutional recognition, to agree in advance to comply with reasonable time, place, and manner regulations concerning the exercise of free speech on campus:

Just as in the community at large, reasonable regulations with respect to the time, the place, and the manner in which student groups conduct their speech-related activities must be respected. A college administration may impose a requirement ... that a group seeking official recognition affirm in advance its willingness to adhere to reasonable campus law. Such a requirement does not impose an impermissible condition on the students' associational rights. Their freedom to speak out, to assemble, or to petition for changes in school rules is in no sense infringed. It merely constitutes an agreement to conform with reasonable standards respecting conduct. This is a minimal requirement, in the interest of the entire academic community, of any group seeking the privilege of official recognition. (Healy v. James 1972, at 180-81)

In summary Tinker v. Des Moines (1969), Healy v. James (1972), and subsequent cases teach that the unique context and the totality of the circumstances must be considered in each case. Student behavior that might constitute a material and substantial interference under one set of circumstances may not in another. The Tinker test is a useful guide, but it still requires school officials to exercise common sense in dealing with the inevitable and endlessly varied disputes over student speech. The Tinker test is both a benchmark for lawfully establishing school authority over student speech and a check and balance against the potential abuse of that authority (Dayton 2015, p. 170).

All U.S. jurisdictions are bound by the U.S. Supreme Court's decisions in Tinker, Healy, and other First Amendment precedents by the Court (Dayton 2015). In some states, however, state constitutional provisions may provide even greater protections for free speech than those recognized under federal law. The federal constitution creates a legal floor-level for the protection of rights. State constitutions may, however, provide for protections above and beyond those guaranteed under the federal constitution. Where state constitutions provide for broader protections of free speech and other rights, state officials must also comply with the mandates of their state's constitution. Although private institutions are not bound by constitutional mandates, many private educational institutions have voluntarily adopted institutional charters, student bills of rights, and policies protecting rights to freedom of expression in their campus communities. These can become binding as law, as part of the contract between the private school and the student.

\section{The Continuing Evolution of Student Speech Law in Public Educational Institutions}

Tinker, Fraser, and Hazelwood are considered well-established law. In Mahanoy School District v. Levy (2021) the Court's most recent case addressing student speech rights, the U.S. Supreme Court clarified the application of these free speech precedents to off-campus and online student speech. In Mahanoy, B. L., a high school student, was not selected for the varsity cheerleading team. Reacting in anger and frustration to this decision, B. L. posted on social media two photos of her and her friends at a local convenience store with raised middle fingers and a photo caption stating: "Fuck school fuck softball fuck cheer fuck everything (Mahanoy School District v. Levy 2021, at 2043)".

B. L.'s conduct occurred during the weekend and off-campus. Other than B. L.'s comments being about school activities, her expression was otherwise unrelated to the school. B. L. only sent these photos to her social media friends. But the photos were eventually shared by others with school officials who disapproved of B. L.'s comments and 
suspended B. L. from participation in the junior varsity cheerleading team. B. L. and her parents challenged the suspension as a violation of free speech rights under Tinker.

In an 8-1 opinion the U.S. Supreme Court ruled in favor of the student, B. L., and against the school, vigorously upholding student speech rights and reaffirming the Court's continuing support for Tinker. Citing Tinker and subsequent related precedents the Court stated: "We have made clear that students do not 'shed their constitutional rights to freedom of speech or expression', even 'at the school house gate' ... minors are entitled to a significant measure of First Amendment protection (Mahanoy School District v. Levy 2021, at 2044)".

Recognizing that student speech rights must be balanced with the legitimate needs of public schools, the Court stated "we have also made clear that courts must apply the First Amendment 'in light of the special characteristics of the school environment (Mahanoy School District v. Levy 2021, at 2044 $\left.{ }^{14}\right)^{\prime \prime \prime}$. The Court recognized these special circumstances included times when school officials were acting in loco parentis ${ }^{15}$, in certain circumstances where student speech was indecent, lewd, or vulgar during school assemblies on school grounds (Bethel v. Fraser 1986, at $685^{16}$ ), and where speech is likely to cause a material and substantial disruption in schools (Tinker v. Des Moines 1969, p. 513). The Court noted: "These special characteristics call for special leeway when schools regulate speech that occurs under its supervision (Mahanoy School District v. Levy 2021, p. 2045)". The Court declared:

[W] do not believe the special characteristics that give schools additional license to regulate student speech always disappear when a school regulates speech that takes place off campus. The school's regulatory interests remain significant in some off-campus circumstances .... These include serious or severe bullying or harassment targeting particular individuals; threats aimed at teachers or other students; the failure to follow rules concerning lessons, the writing of papers, the use of computers, or participation in other online school activities; and breaches of school security devices, including material maintained within school computers. (Mahanoy School District v. Levy 2021, p. 2045)

The Court concluded, however, that aside from the vulgar language in a clearly offcampus venue, B. L.'s speech involved criticism of school rules and decisions, speech that is protected by the First Amendment, and nothing in this case put B. L.'s speech outside of the protections of the First Amendment: "To the contrary, B. L. uttered the kind of pure speech to which, were she an adult, the First Amendment would provide strong protection (Mahanoy School District v. Levy 2021, at 2046-47)". The Court further noted:

Consider too when, where, and how B. L. spoke. Her posts appeared outside of school hours from a location outside the school. She did not identify the school in her posts or target any member of the school community with vulgar or abusive language. B. L. also transmitted her speech through a personal cellphone, to an audience consisting of her private circle of Snapchat friends. These features of her speech, while risking transmission to the school itself, nonetheless ... diminish the school's interest in punishing B. L.'s utterance.

(Mahanoy School District v. Levy 2021, at 2047)

\section{Freedom of the Press in Public Educational Institutions}

Freedom of the press holds an exalted role in the establishment and advancement of American democracy, with the First Amendment prohibiting any law "abridging the freedom of speech, or of the press (U.S. Const. amend. I)". You can ascertain whether a nation is genuinely a free democracy by examining the true status of its citizen press 
(Dayton 2015, supra note 1, at 67-69; Epps 2008). Concerning the student press, it must be remembered that today's student journalist may be tomorrow's best hope for exposing corruption, informing the public, and speaking for the people through a free press nationally and internationally.

In general, government officials must not interfere with free speech or press. There are, however, times and circumstances in which reasonable limitations on speech and press are warranted. Government efforts to control journalists and the free press generally fall into two categories: Prior restraints and post-publication punishments. The constitutional hazards of both prior restraints and post-publication punishments are that they may dangerously permit government agents to improperly abridge free speech and press. Prior restraints prevent free speech and press, and post-publication punishments have a chilling effect on free speech and press. While both types of controls present constitutional dangers, courts view prior restraints as the greater danger, and for this reason prior restraints are generally judicially disfavored (Dayton 2015, pp. 183-84).

In public educational institutions prior restraints historically have manifested as administrators' demands that students' publications be officially sanctioned by the institution and subject to prior review and censorship by school officials. Post-publication punishments have included student suspensions and expulsions, civil suits, and referrals to law enforcement agents for prosecutions. There may sometimes be a legitimate basis for these actions. But under the First Amendment government officials have no legitimate role in "protecting" others from the truth or protecting themselves from public criticisms; no legitimate rights to use government powers and coercive force to hide their own mistakes and misconduct; and telling the truth can never be criminalized without risking grave damage to both freedom and public safety. The truth not only sets us free, it helps to keep us safe. Legitimate rights of free speech and press must be rigorously protected (Dayton 2015).

Whether speech or press communications are protected or subject to reasonable government regulations and sanctions depends on the facts and circumstances of the case. In public educational institutions, if the facts and circumstances identify communications as individual student speech, the Tinker standard applies: School officials may only limit individual student expression if they can establish it would "materially and substantially interfere with the requirements of appropriate discipline in the operation of the school (Tinker v. Des Moines 1969, p. 509)". Additionally, "where there is no finding and no showing that engaging in the forbidden conduct" meets this standard "the prohibition cannot be sustained (Tinker $v$. Des Moines 1969)". While prior restraints on speech and press are generally disfavored, prior restraints may be permitted under the Tinker standard. The Tinker test does not require school officials to prove there was an actual disruption, nor are school officials required to allow the disruption to occur before intervening (Dayton 2015, supra note 1 , at 147$)$.

If facts and circumstances identify communications as school sponsored speech, school officials have much broader authority concerning these communications. Concerning student expression in public school sponsored forums, under the Hazelwood test school officials are only required to establish "legitimate pedagogical concerns", i.e., there was a legitimate educational rationale for limiting student speech in the school sponsored forum (Hazelwood v. Kuhlmeier 1988). School sponsored forums include school sponsored publications, lectures, convocations, performances, athletic events, and other expressive activities students and other members of the public would reasonably perceive as bearing the "imprimatur of the school (Dayton 2015, supra note 1, at 158)".

Government officials may always apply reasonable time, place, and manner (TPM) restrictions to expressive conduct on campus, including student press activities. TPM restrictions are considered reasonable if they are: (1) content neutral; (2) narrowly tailored to serve a significant governmental interest; and (3) leave open an adequate alternative channel of communication (Dayton 2015, supra note 1, at 157). Further, government officials may also limit speech and press by establishing a compelling governmental interest for the 
limitations and that no less restrictive alternative exists (Dayton 2015). Concerning actions that threaten imminent dangers, for example, as the Court held in Brandenburg v. Ohio 1969 government officials may act to prohibit and punish acts provoking imminent dangers if "such advocacy is directed to inciting or producing imminent lawless action and is likely to incite or produce such action (Brandenburg v. Ohio 1969, at 447)".

But while these latter powers (i.e., proving compelling interests or imminent dangers) are available to government officials, school officials rarely have needs to exercise the authority recognized under Brandenburg, and can more easily apply Tinker, Hazelwood, and reasonable TPM regulations (Dayton 2015, p. 185). A public school is not a public street. In most cases school officials may enforce more rigorous standards of conduct on students and on campus than could constitutionally be enforced on citizens and public areas not under school control (Dayton 2015). Even in state institutions of higher education, the Court in Healy v. James 1972 cited Tinker v. Des Moines 1969 in holding that university officials do not have to tolerate student activities that breach reasonable campus rules; interrupt the educational process; or interfere with other students' rights to receive an education, recognizing a far more deferential standard of review for school officials than is required under the Brandenburg test (Healy v. James 1972).

Like many other areas of law, significant unresolved issues remain concerning the proper boundaries of individual rights and institutional authority related to free speech and press. The Court's decision in Hazelwood v. Kuhlmeier 1988, however, is increasingly recognized as the guiding precedent for student publications in all public educational institutions, including higher education institutions. Retreating from more stringent protections of campus newspapers in the 1970s, many lower courts have now embraced Hazelwood as a precedent in university student press cases, despite the obvious differences between editors, staff, and audiences for a high school and university student newspaper (Dayton 2015, supra note 95, at 186). Minimizing these distinctions, and following Hazelwood as legal precedent, these courts distinguish between expression that is purely private in nature and subject only to general limitations on free speech and expression that is sponsored, controlled, or reasonably perceived as attributable to the educational institution (Dayton 2015).

In summary, all expression on campus is subject to some general limits, e.g., a purely private publication distributed on campus and not school sanctioned would still be subject to reasonable TPM restrictions imposed by school officials. Further, student editors and staff are subject to the same rules and limitations that apply to all other students. And under Hazelwood, while any censorship based on content raises serious First Amendment concerns, in a school sponsored non-public forum, e.g., a school journalism class, play, etc., reasonable content-based limitations may be imposed for legitimate pedagogical purposes.

\section{Conclusions}

Viewed together, the Court's cases indicate that student speech in public educational institutions generally falls into one of two categories: (1) student speech involving individual student expression, as in Tinker v. Des Moines 1969, or (2) student speech in school sponsored forums, as in Bethel v. Fraser 1986 and Hazelwood v. Kuhlmeier 1988. In Tinker the Court declared that to lawfully limit individual student speech, school officials must establish that the speech would "materially and substantially interfere with the requirements of appropriate discipline in the operation of the school (Tinker v. Des Moines 1969, 509)". Although school officials may apply reasonable time, place, and manner restrictions to all expressive activities, if they cannot establish that the speech "materially and substantially" (Tinker v. Des Moines 1969) interferes with "appropriate discipline in the operation of the school" (Tinker v. Des Moines 1969) the speech generally cannot be prohibited or punished consistent with the First Amendment.

Tinker was a 7-2 decision in which the majority of the Court solidly endorsed the vigorous protection of free speech rights for students and faculty (Tinker v. Des Moines 1969). In Tinker, it was clear that the Court expected school officials to take the First Amendment 
seriously. The Court declared in Tinker: "The Constitution says that Congress (and the States) may not abridge the right to free speech. This provision means what it says (Tinker $v$. Des Moines 1969, at 513)". The Court established a high burden of proof in Tinker, because school officials are being asked to justify silencing what would otherwise be protected free speech under the Constitution. But the Court also wanted to make clear that school officials had legitimate authority to apply reasonable limits to student speech when necessary. The Court's "material and substantial interference" standard in Tinker attempts to strike a reasonable balance in these competing concerns, and to provide some guidance to school officials and judges in fairly resolving disputes over these issues (Dayton 2015, supra note 1 , at 146-47).

Concerning student speech in public school sponsored forums and other expressive activities that students and community members might reasonably perceive as bearing the "imprimatur of the school" school officials generally have much broader discretion to limit student speech. Where the forum for expression is sponsored by the school or reasonably perceived as bearing the imprimatur of the school, as in Fraser, and Hazelwood, student expression can be limited based on establishing a legitimate educational rationale for limiting the speech (Dayton 2015). Legitimate educational rationales for limiting speech in a school sponsored forum may include, for example, the need to teach civility, limit messages inconsistent with legitimate educational goals, teach professional responsibility, etc. (Dayton 2015).

The Court's tests in Tinker and Fraser/Hazelwood continue to provide useful guidance for school officials, lawyers, and judges in sorting out what student speech is protected, what student speech may be prohibited, and in proactively establishing lawful policies and practices concerning student speech (Mahanoy School District v. Levy 2021). The Court's decades long evolution of free speech law has resulted in useful guidance in balancing free speech with legitimate institutional needs. Further, the brave actions of persons like Mary Beth Tinker, her family, and countless other students and families courageously standing up for our First Amendment will continue to assure that school officials and all government officials are kept honest and accountable in respecting essential human rights of free speech. The law governing student speech will continue to evolve, with Tinker as its bedrock foundation (Tinker v. Des Moines 1969).

Author Contributions: The authors contributed equally to the article. All authors have read and agreed to the published version of the manuscript.

Funding: This research received no external funding.

Institutional Review Board Statement: Not applicable.

Informed Consent Statement: Not applicable.

Data Availability Statement: Not applicable.

Conflicts of Interest: The authors declare no conflict of interest.

\section{References \\ Primary Sources}

Abrams v. U.S. 1919. 250 U.S. 616.

Bethel v. Fraser. 1986. 478 U.S. 675.

Brandenburg v. Ohio. 1969. 395 U.S. 444.

Cohen v. California. 1971. 403 U.S. 15.

Hazelwood v. Kuhlmeier. 1988. 484 U.S. 260.

Healy v. James. 1972. 408 U.S. 169.

Hosty v. Carter. 2005. 412 F.3d 731 (7th Cir. 2005).

Mahanoy School District v. Levy. 2021. 141 S. Ct. 2038.

Martin v. Parrish. 1986. 805 F.2d 583 (5th Cir. 1986).

Morse v. Frederick. 2007. 551 U.S. 393.

New Jersey v. T.L.O. 1985. 469 U.S. 325. 
Schenck v. United States. 1919. 249 U.S. 47.

Tinker v. Des Moines. 1969. 393 U.S. 503.

U.S. Const. amend. I (1791).

United States v. Schwimmer. 1928. 279 U.S. 644, 655.

Wilson v. Chancellor. 1976. 418 F. Supp. 1358, 1368 (D. Or. 1976).

\section{Published Sources}

Dayton, John. 2015. Higher Education Law: Principles, Policies, and Practices. Athens: Wisdom Builders Press.

Dayton, John. 2019. Education Law: Principles, Policies, and Practice. Athens: Wisdom Builders Press.

Dayton, John. 2020. Legal Research, Analysis, and Writing. Athens: Wisdom Builders Press.

Dupre, Anne Proffitt. 2008. The Story of Hazelwood School District v. Kuhlmeier: Student Press and the School Censor. In Education Law Stories. Edited by Michael A. Olivas and Ronna Greff Schneider. Sunderland: Foundation Press, pp. 221-57.

Epps, Garrett, ed. 2008. The First Amendment: Freedom of the Press: Its Constitutional History and the Contemporary Debate. Amherst: Prometheus Books.

Golby, Jessica. 2006. The case against extending Hazelwood v. Kuhlmeier's public forum analysis to the regulation of university student speech. Washington University Law Review. 84: 1263.

LaVigne, Christopher N. 2008. Hazelwood v. Kuhlmeier and the university: Why the high school standard is here to stay. Fordham Urban Law Journal 35: 1191.

Martin, Karyl Roberts. 2003. Demoted to high school: Are college students' free speech rights the same as those of high school students. Boston College Law Review. 45: 173.

Nimick, Virginia J. 2006. Schoolhouse rocked: Hosty v. Carter and the case against Hazelwood. Journal of Law and Policy 14: 941. 